\title{
SOSIALISASI PENGUNAAN MASKER DAN PEMBAGIAN MASKER KEPADA WARGA UNTUK PENCEGAHAN COVID 19 DI PASAR TRADISIONAL KOTA BENGKULU
}

\author{
Fernalia ${ }^{1}$, Pawiliyah ${ }^{2}$, Ida Rahmawati ${ }^{3}$, Loren Juksen ${ }^{4}$, Sanisahhuri ${ }^{5}$, Syamsu \\ Rizal $^{6}$
}

\section{1,2,3,4,5,6 STIKES Tri Mandiri Sakti}

Email : lia_fernalia@yahoo.com, pawiliyah@yahoo.com, idarahmawati1608@yahoo.com, juksenloren@yahoo.com

\begin{abstract}
ABSTRAK
Masker adalah alat pelindung diri yang dirancang untuk melindungi pengguna dari menghirup partikel udara dan melindungi kesehatan saluran pernafasan. Penggunaan masker mengurangi infeksi influenza dan coronavirus pada manusia dengan mencegah penyebaran percikan yang dapat menyebabkan infeksi dari orang yang terinfeksi ke orang lain dan kemungkinan kontaminasi lingkungan. Badan Stistik Nasional (2020) melaporkan pada Juni 2020 kasus yang terkonfirmasi diseluruh dunia berjumlah 163.973 kasus. Tim Gugus Tugas Percepatan Penanganan COVID-19 Indonesia melaporkan angka kejadian per 30 Juni dilaporkan sebanyak 1293 kasus. Angka kejadian di Provinsi Bengkulu per Juni dilaporkan ada 124 kasus dan 10 orang meninggal dunia dan dari angka kasus tersebut 7 orang terkonfirmasi sebagai pedagang di pasar tradisional, artinya pasar menjadi cluster baru penyebaran COVID 19 di Kota Bengkulu. Tujuan pengabdian masyarakat ini adalah memberikan pemahaman dan meningkatkan kesadaran masyarakat tentang manfaat dan pentingnya penggunaan masker. Kegiatan yang dilakukan dengan metode ceramah dengan memberikan informasi tentang penggunaan masker dan memberikan masker kepada masyarakat di pasar tradisional Kota Bengkulu. Terdapat perubahan pengetahuan tentang penggunaan masker di masyarakat pasar tradisional kota Bengkulu terhadap COVID 19 dengan demikian sosialisasi penggunaan masker dan pemberian masker di pasar trasional sangat efektif untuk peningkatan pengetahuan dan merubah pola kebiasaan pedagang dan pembeli untuk mengikuti protokol kesehatan yang aman dalam upaya pencegahan dan memutus rantai penyebaran COVID-19. Diharapkan dengan melakukan penyuluhan dan sosialisasi ini masyarakat semakin sadar dan peduli akan pencegahan COVID 19 dengan memakai masker dengan menggunakan masker.
\end{abstract}

Kata Kunci: sosialisasi, penggunaan masker, COVID-19 , Pasar Tradisional

\begin{abstract}
Masks are personal protective equipment designed to protect the wearer from inhaling air particles and protect the health of the respiratory tract. The use of masks reduces influenza and coronavirus infections in humans by preventing the spread of splashes that can cause infection from an infected person to another and possible environmental contamination. The National Statistics Agency (2020) reported that in June 2020 confirmed cases worldwide totaled 163,973 cases. The Task Force Team for the Acceleration of Handling COVID-19 in Indonesia
\end{abstract}


reported that the number of incidents as of June 30 was reported as 1293 cases. The number of incidents in Bengkulu province as of June was reported to have been 124 cases and 10 people died and of these cases 7 people were confirmed as traders in traditional markets, meaning that the market became a new cluster for the spread of COVID 19 in Bengkulu City. The purpose of this activity is; Provide understanding and increase public awareness about the benefits and importance of using masks. Activities carried out in the form of socialization by providing information about the use of masks and giving masks to the community in the traditional markets of the city of Bengkulu. There has been a change in knowledge about the use of masks in the traditional market communities of Bengkulu City against COVID 19 thus socializing the use of masks and giving masks in the traditional market is very effective to increase knowledge and change the habit patterns of traders and buyers to follow safe health protocols in an effort to prevent and break the chain of spread of COVID-19. It is hoped that by carrying out counseling and socialization, the community will be more aware and concerned about the prevention of COVID 19 by wearing masks

Keywords: Socialization, Use of Masks, COVID-19, Traditional Market

\section{PENDAHULUAN}

Corona Virus 19 (COVID-19) merupakan salah satu penyakit yang disebabkan oleh corona virus yang merupakan kasus pandemik sejak tanggal 11 Maret 2020. Corona viruses (CoV) adalah bagian dari keluarga virus yang menyebabkan penyakit mulai dari flu hingga yang lebih berat yaitu: Severe Acute Respiratory Syndrome (SARS-CoV) dan Middle East Respiratory Syndrome (MERS-CoV). Penyakit yang disebabkan virus corona, atau dikenal dengan COVID-19, adalah suatu jenis yang baru dan ditemukan di akhir tahun 2019 dan sebelumnya tidak pernah teridentifikasi menyerang manusia (Widiyani, 2020). Covid-19 atau sering disebut Coronavirus disease 2019 merupakan penyakit yang menginfeksi saluran pernapasan akut dan disebabkan oleh Coronavirus Strain Severe Acute Respiratory Syndrome Coronavirus 2 (SARS-CoV-2 yang kali pertama teridentifikasi di 2019 akhir, tepatnya di kota Wuhan, Provinsi Hubei Cina (Beiu et al., 2020).

Penyakit ini dengan sangat mudah menyerang pernapasan, namun dari berbagai riset yang dilakukan, hasil riset menunjukkan bahwa tingkat kematian pada wabah jenis ini diakibatkan karena adanya penyakit penyerta seperti penyakit serebrovaskular, hipertensi diabetes mellitus dan jantung coroner (Fang et al., 2020). Beberapa gejala yang terjadi seperti letih, demam, sesak nafas, batuk, dan tidak nafsu makan. Dan berbeda dengan influenza, Covid-19 dengan sangat cepat dapat berkembang hingga mengakibatkan terjadinya infeksi lebih parah dan gagal organ bahkan kematian. Terjadinya kondisi darurat semacam ini utamanya pada pasien dengan masalah kesehatan sebelumnya (Mona, 2020).

Menurut Erlina Burhan (2020), hasil analisis data tentang coronavirus menunjukkan bahwa COVID-19 memiliki angka kematian sekitar 2\%-3\%, jauh lebih rendah dari wabah lain (SARS, MERS, Swine Flu). Sehingga masyarakat tidak perlu panik tetapi tentunya tetap waspada dengan melakukan pencegahan sesuai dengan anjuran. Untuk mengantisipasi 
penyebarannya, maka penggunaan masker disertai dengan peningkatan kebiasaan penggunaan pembersih tangan yang mengandung alkohol atau mencuci tangan dengan menggunakan air dan sabun menjadi salah satu upaya yang direkomendasikan terutama bagi yang sedang merawat pasien terinfeksi Coronavirus dan orang yang mengalami gejala batuk, demam dan gangguan pernapasan (WHO, 2020).

Data WHO (2020) menunjukkan bahwa total kasus COVID-19 di dunia pertanggal 14 Juli 2020 menjadi 12.880 .565 kasus terkonfirmasi positif dengan 568.573 kematian (https: / / who.int). Indonesia merupakan salah satu negara yang terkena virus COVID-19 dan sudah menyebar diseluruh provinsi di Indonesia. Total kasus terkonfirmasi positif di Indonesia per tanggal 14 Juli 2020 menjadi 78.572 kasus dengan 3.710 meninggal (4,7\% dari kasus terkonfirmasi) dan 37.636 sembuh $(47,9 \%$ dari kasus terkonfirmasi (Kemenkes, 2020)

Berdasarkan data KEMENKES RI menunjukkan bahwa kasus yang positif ditemukan mayoritas pada usia 25 - 54 tahun (Kemenkes, 2020). Sumatera Utara merupakan salah satu provinsi di Indonesia yang juga terkena dampak pandemi covid-19. Jumlah kasus terkonfirmasi positif di Provinsi Sumatera Utara mengalami peningkatan kasus setiap harinya. Total kasus terkonfirmasi positif di Provinsi Sumatera Utara per tanggal 14 Juli 2020 menjadi 2.497 kasus dengan 131 meninggal dan 597 sembuh (http://covid19.sumutprov.go.id).

Berdasarkan KMK HK.01.07/MENKES/413/2020 menetapkan pedoman pencegahan dan pengendalian COVID-19 di masyarakat diantaranya physical distancing, menjaga kebersihan tangan, etika batuk/bersin, pemakaian masker, pembatasan aktivitas luar rumah, mempertimbangkan pembatasan sosial berskala besar (PSBB), memastikan akses kebersihan tangan di depan gedung fasilitas umum dan pusat transportasi dengan menyiapkan fasilitas cuci tangan (Kemenkes, 2020).

Pengetahuan mengenai cara dalam pemeliharaan kesehatan dan cara menghindari penyakit, dengan sendirinya meningkatkan pengetahuan masyarakat (Juwariyah \& Priyanto, 2018). Pengetahuan tentang Corona virus adalah hal yang sangat urgent, sehingga tidak terjadi peningkatan jumlah kasus. Pemahaman masyarakat tentang virus corona dapat diartikan sebagai hasil tahu masyarakat mengenai cara pencegahan, pengobatan dan komplikasinya (Mona, 2020). Dalam hal penentuan perilaku pengetahuan memiliki peran penting dikarenakan pengetahuan akan membentuk kepercayaan dalam mempersepsikan kenyataan, memberikan dasar bagi pengambilan keputusan serta penentuan perilaku akan suatu objek (Yuliastuti et al., 2014) sehingga punya pengaruh terhadap perilaku seseorang. Utamanya pada orang dewasa terbentuk suatu perilaku dimulai pada domain kognitif dalam artian subjek tahu lebih dahulu pada stimulus yang merupakan materi ataupun objek diluarnya, hingga timbulnya suatu pengetahuan baru dalam sikap ataupun tindakan.

Pengetahuan masyarakat mengenai pencegahan penularan corona dan kepatuhan Pemakaian masker mempunyai peran yang penting dalam hal antisipas kejadian berulang. Masyarakat mesti mempelajari, mengenal 
serta memahami berbagai aspek dari jenis penyakit corona termasuk penyebab, tanda dan gejala, pencetus serta penatalaksanaannya. Suatu pengetahuan punya keterkaitan yang erat terhadap suatu keputusan yang akan diambilnya, karena seseorang menentukan pilihan berdasarkan landasan dari pengetahuan yang dimilikinya (Prihantana \& Wahyuningsih, 2016).

Kepatuhan merupakan istilah dalam menggambarkan perilaku suatu kelompok masyarakat dalam penggunaan masker. Kepatuhan adalah perilaku positif yang diperlihatkan masyarakat saat masyarakat menggunakan masker. Pengetahuan, motivasi, pengetahuan, persepsi, dan keyakinan terhadap upaya pengontrolan dan pencegahan penyakit, kualitas intruksi kesehatan, variabel lingkungan, serta kemampuan dalam mengakses sumber yang ada merupakan factor-faktor yang turut mempengaruhi (Sinuraya et al., 2018) Upaya komprehensif, dalam rangka pencegahan serta pengendalian yang dapat membatasi penyebaran penyakit-penyakit virus saluran pernapasan, termasuk COVID-19 adalah dengan penggunaan masker. Masker dapat digunakan baik untuk melindungi orang yang sehat dan juga untuk orang yang terinfeksi untuk mencegah penularan lebih lanjut.

Salah satu anjurannya adalah dengan masyarakat menggunakan masker saat di luar rumah. Jenis masker yang dapat digunakan adalah masker kain yang merupakan salah satu contoh dari masker non medis atau disebut pula dengan masker komunitas yang merupakan penutup muka buatan sendiri atau komersial yang terbuat dari kain. Kendati masker non medis tersebut bisa pula dari tekstil lain atau bahan lain seperti kertas yang dapat digunakan oleh masyarakat yang bukan termasuk pemberi atau petugas pelayanan kesehatan (ECDC, 2020).

Tujuan pengabdian masyarakat ini yaitu memberikan pemahaman dan meningkatkan kesadaran warga tentang manfaat dan pentingnya penggunaan masker saat sedang berada di luar rumah .

\section{MASALAH}

Alasan tim melakukan sosialisasi pengunaan masker dan pembagian masker kepada warga. Pasar tradisional merupakan pusat perekonomian dan sebagai pusat aktifikas bagi warga, disamping hal tersebut sebagian warga kurang kesadaran untuk mematuhi protokol kesehatan seperti tidak menggunakan masker, tidak menjaga jarak, tidak mencuci tangan setelah bertransaksi sehingga menjadi sarana penyebaran COVID 19. Hal ini menjadi dasar tim untuk melakukan sosialisasi. 


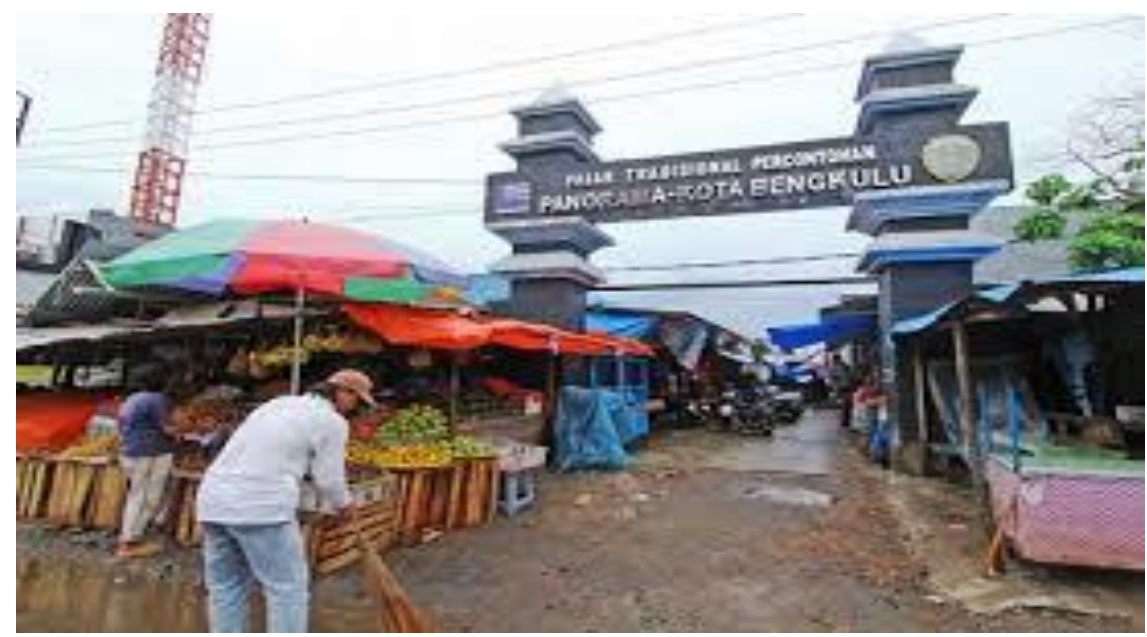

Gambar 2.1 Lokasi sosialisasi pengunaan masker dan pembagian masker kepada warga di Pasar Tradisional Bengkulu.

\section{METODE}

1. Tujuan Persiapan

Tahap persiapan dari kegiatan adalah survey lokasi,pengurusan perizinan ke dinas terkait, menyiapkan pre planing, penentuan titik lokasi, persiapan masker, sound sistem yang siapakan oleh pihak penyelenggara dan pembuatan bahan penyuluhan dilakukan sebelum waktu pelaksanaan ( 24 Juli 2020)

2. Tahap pelaksanan

dilakukan dengan metode ceramah mengenai bagaimana cara penggunaan masker dan pemberian masker kapada warga di pasar tradisional Kota Bengkulu.

3. Evaluasi

1. Struktur

Peserta adalah seluruh warga yang berada di pasar tradisional Kota Bengkulu. Tempat pelaksanaan sudah sesuai dengan rencana yang dibuat dan perlengkapan yang dilakukan untuk Peran pelaksana sudah sesuai dengan tugas yang telah di tetapkan, baik sebagai penanggung jawab, tim pemberian masker dan dokumentasi.

2. Proses

Pelaksanaan kegiatan dilakukan pada hari 24 Juli 2020 pukul $06.30 \mathrm{~S} / \mathrm{d}$ 14.00 wib sesuai dengan jadwal yang telah di rancanakan.

3. Hasil

Untuk meningkatkan kesadaran masyarakat tentang manfaat dan pentingnya penggunaan masker dalam mematuhi protokol kesehatan dalam upaya pencegahan dan memutus rantai penyebaran COVID-19. 


\section{HASIL DAN PEMBAHASAN}

Metode pelaksanan dalam kegiatan ini adalah melakukan sosialisasi penggunaan masker dan pemberian masker untuk mencegah serta memutus rantai penyebaran Corona Virus Disease 19 melalui informasi penggunaan masker di pasar tradisional yang dilaksanakan pada tanggal 24 Juli 2020. Pelaksanaan sosialisasi penggunaan masker dan pemberian masker untuk mencegah serta memutus rantai penyebaran COVID 19 ditunjukan untuk seluruh warga di pasar Tradisional Kota Bengkulu. Media dan alat yang di gunakan berupa sound sistem, masker dan metode yang digunakan adalah ceramah dengan memberikan informasi tentang penggunaan masker. Berikut dokumentasi pelaksanaan sosialisasi pengunaan masker dan pembagian masker kepada warga untuk pencegahan COVID 19 di pasar Tradisional Kota Bengkulu.

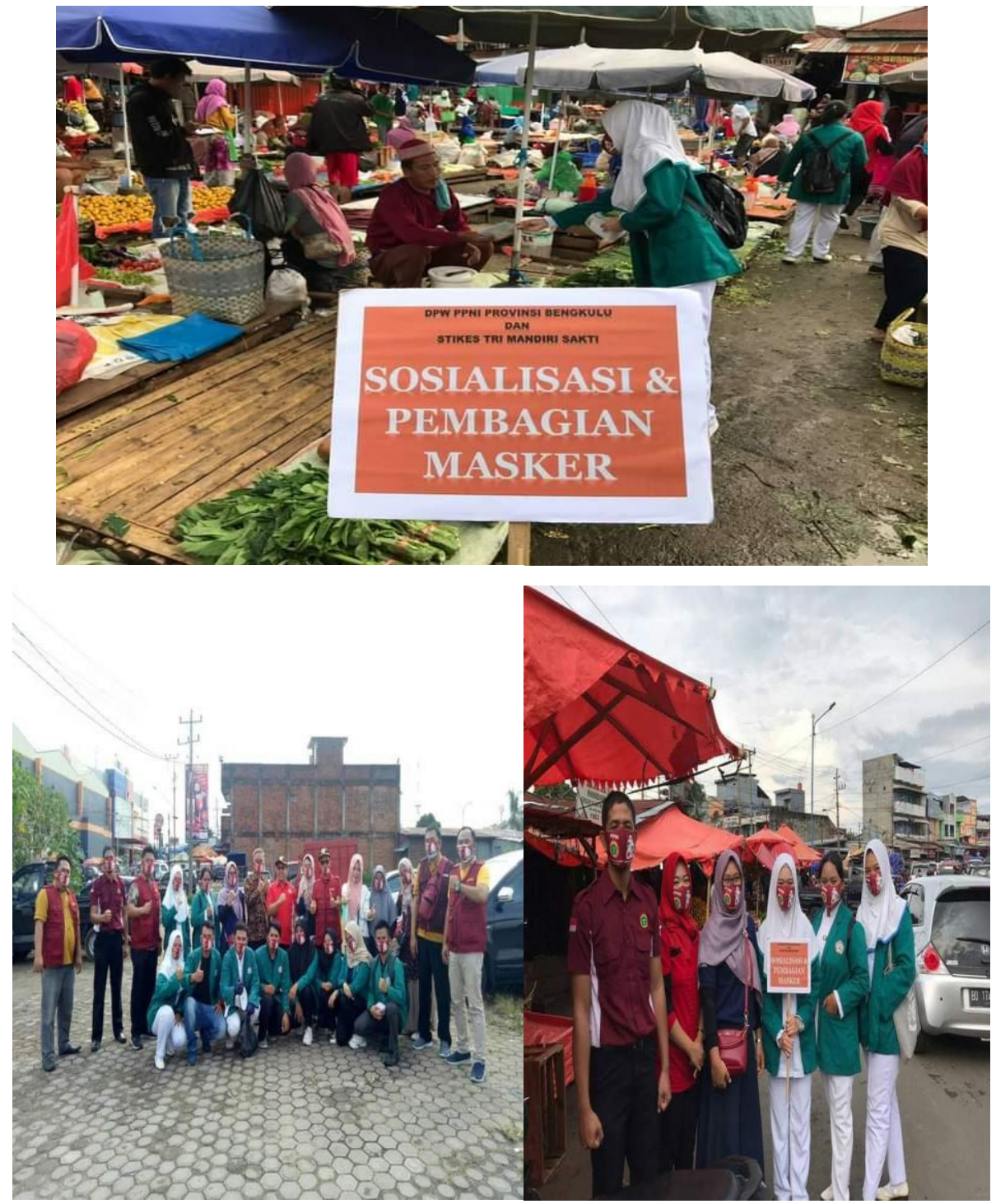




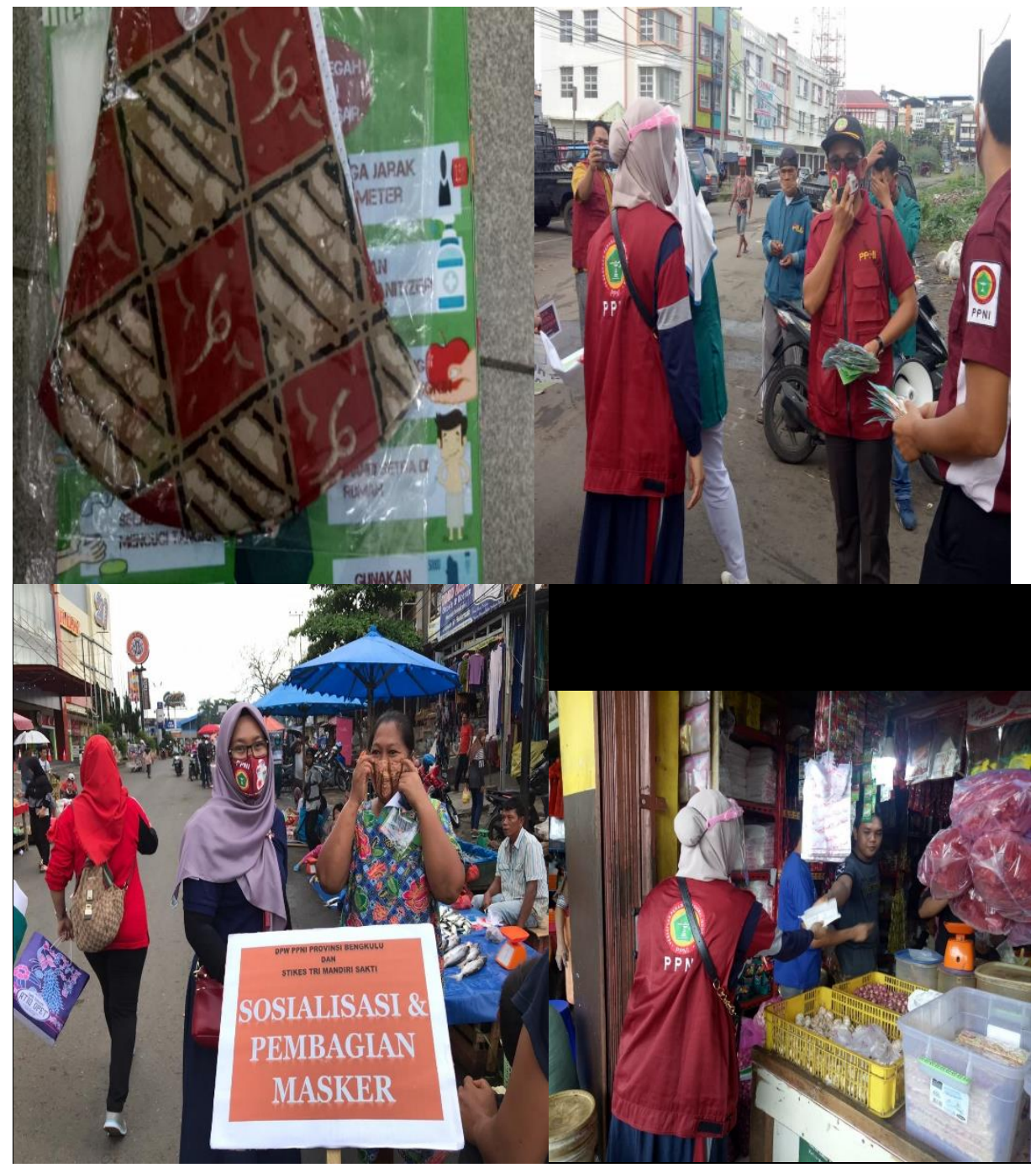

\section{KESIMPULAN}

Berdasarkan hasil kegiatan pengabdian masyarakat mengenai sosialisasi pengunaan masker dan pembagian masker kepada warga untuk pencegahan covid 19 di pasar tradisional Kota Bengkulu, maka dapat di simpulakan bahwa sosialisai berpengaruh terhadap peningkatan kesadaran masyarakat tentang manfaat dan pentingnya penggunaan masker dalam mematuhi protokol kesehatan dalam upaya pencegahan dan memutus rantai penyebaran COVID-19. 


\section{DAFTAR PUSTAKA}

Ardiputra dkk .(2020). pembagian masker dan sosialisasi kebijakan pemerintah dalam rangka mendukung pencegahan penyebaran covid-19 pada masyarakat desa pallis kecamatan balanipa. 1 (3) 393-400.

Depkes RI. (2020). Pedoman Pencegahan dan Pengendalian Corona Virus Desease (COVID-19). Jakarta: Kemenkes RI \& Dirjen Pencegahan dan Pengendalian Penyakit.

Erlina Burhan (2020). Coronavirus Yang Meresahkan Dunia. J Indon Med Assoc, Volum: 70, Nomor: 2, Februari 2020. http://mkiojs.idionline.org/jurnal/article/download/170/98.

Fitdayanti dkk .(2020). Pencegahan Covid-19 Melalui Pembagian Masker Di Kelurahan Romang Polong Kabupaten Gowa 2 (1) 53-57

Kemenkes RI .(2020). Pedoman Pencegahan Dan Pengendalian Corona Virus Diseases (COVID-19). Direktorat Jenderal Pecegahan dan Pengendalian Penyakit. KMK No. HK. 01.07-MENKES- 413-2020 tentang Pedoman Pencegahan dan Pengendalian COVID-19

Mona, N. (2020). Konsep Isolasi Dalam Jaringan Sosial Untuk Meminimalisasi Efek Contagious (Kasus Penyebaran Virus Corona Di Indonesia). Jurnal Sosial Humaniora Terapan, 2(2).

Munthe., Manurung., Sinaga. (2020) penyuluhan dan sosialisasi masker di desa sifahandro kecamatan sawo sebagai bentuk kepedulian terhadap masyarakat ditengah mewabahnya virus covid 19 1,(2) 115-123.

Situasi COVID-19 di Sumatera Utara. (2020). http://covid19.sumutprov.go.iddiakses 14 Juli 2020.

WHO. (2020) Coronavirus Disease $\quad$ (COVID-19).

Dashboardhttps://covid19.who.intdiakses 14 September2020 